ISSN: 2146-0574, eISSN: 2536-4618

Biyoloji / Biology

DOI: $10.21597 / j i s t .741467$

Araştırma Makalesi / Research Article

Geliş tarihi / Received: 28-05-2020

Kabul tarihi / Accepted: 02-10-2020

\title{
Seasonal Variation of Fatty Acid Composition in Muscle Total Lipids of Male and Female Individuals of Alburnus tarichi
}

\author{
Veysi KIZMAZ ${ }^{*}$, Mehmet BAŞHAN², Tarık ÇiÇEK ${ }^{2}$
}

\begin{abstract}
In our study, sixteen types of fatty acids were determined as a result of muscle tissue analysis, among which, out of saturated fatty acids, 16:0; out of monounsaturated ones, 16:1n-7 and 18:1n-9; and out of polyunsaturated ones, 20:5n-3 and 22:6n-3 were major. Other fatty acids were found in trace amounts. Out of saturated fatty acids, 16:0 was found to be $14.94 \%$ on average in females and 15.34\% in males. 16:0 increased in August in both sexes. The ratio of 18:0 was at the level of 4\% in both sexes. Furthermore, this component was found to fluctuate depending on the months. 16:1n-7 was $13.28 \%$ in female individuals and $13.16 \%$ in males. The ratio of $18: 1 \mathrm{n}-9$, which was the other major MUFA component, was $21.67-25.40 \%$ in females, while it was $20.63-27.73 \%$ in male individuals. It was observed that this component decreased in both sexes in February, while it increased in females in October and in male fish in August. The ratio of 20:5n-3, which is another polyunsaturated component, did not change significantly among months, with an average value of $11.60 \%$ in females and $10.93 \%$ in males. The ratio of 22:6n-3, which was found as the other major one, decreased in October with a rate of $12.61 \%$ in females and $12.67 \%$ in males and showed a similar distribution in the other months.

In the analyses, the ratio of $\omega 3 / \omega 6$, which is important in terms of the nutritional value of fish, was determined as 3.97 on average in females and 3.88 on males. These components increased in December in both sexes, whereas they decreased in February. We determine $\sum$ SFA increased in August in both sexes, and $\sum$ MUFA increased in October, but $\sum$ PUFA decreased in the same month. In all analyzed months, $\sum$ MUFA and $\sum$ PUFA were more than $\sum$ SFA in both sexes.
\end{abstract}

Keywords: Fatty Acid, Alburnus tarichi, Van Lake

\footnotetext{
${ }^{1}$ Veysi KIZMAZ (Orcid ID: 0000-0002-7864-5912), Vocational Higher School of Healthcare Studies Medical Laboratory Techniques, Mardin Artuklu University, Mardin, Turkey

${ }^{2}$ Mehmet BAŞHAN (Orcid ID: 0000-0002-1228-9548), Tarık ÇiÇEK (Orcid ID: 0000-0001-8491-5598), Dicle University, Department of Biology, Faculty of Science, Diyarbakir, Turkey

*Sorumlu Yazar/Corresponding Author: Veysi KIZMAZ, e-mail: vkizmaz@yahoo.com

*This study was produced from Veysi KIZMAZ's PhD thesis.

Sabahattin Payzin Health Sciences Research and Application Center Experimental Animals Local Ethics Committee "Ethics committee approval was obtained with protocol number 2012/27.
} 


\section{INTRODUCTION}

The fish are divided into three groups as lean, medium-fat, and fatty, according to the amount of fat they contain. Fish are classified as lean if the fat they contain is less than 5\%, medium- fat if it is between 5-10\% and fatty if it is more than 10\% (Ackman 1989, Ackman 1990, Dean, 1990). Since the ratio of fat in freshwater fish is less than 5\%, they are regarded as the lean class. Fish with low fat content has been reported to have high water content and their meats are whiter (Feeley et al., 1972). Especially lean fish usually store lipids in muscle and liver tissue. However, muscle tissues of mammals and trout are lean since they store lipids in fat tissue (Huss, 1988). The tissue in which fat is stored varies depending on the fish type. Moving fish store fat in muscle tissue, while fish living in the bottom of water store it in their livers (Castell et al., 1972). In the studies carried out on freshwater fish, total lipid content was found to be in the range of 0.6-30\% (Atchison, 1975; Farkas and Csengeri, 1976; Dave et al., 1976; Farkas et al., 1978). It was reported that this distribution in total lipid changes according to whether the fish is natural or farm fish (Nettleton and Exler, 1992; George and Bhopal, 1995), climate conditions (Osaka et al., 2002), season (Berg et al., 2000), development of gonad (Uysal and Aksoylar, 2005), sex and size of fish (Osibona et al., 2009), age and geographic regions (Su et al., 2004).

The fats in fish meat both increase the quality of the fish and make it delicious. Especially, the unsaturated fats it contains are important for the organism. Out of these components in fish fats, Eicosapentaenoic acid (EPA) and DHA are very important components in terms of their functions in learning and vision. Arachidonic acid and EPA, which are physiologically active substances, are the precursors of eicosanoids (Whelan et al., 1993; Reilly et al., 1998). EPA and DHA have been reported to have positive effects on many diseases, from cardiovascular diseases to cancer (Steffens and Wirth, 2005). Many studies have been carried out on the lipid components of fish due to their health benefits.

Since Pearl Mullet (Alburnus tarichi) is the only fish species that can live in Lake Van and it is responsible for 1/3 of fish production in the region and inland waters of Turkey (Sar1, 1997) in our study, it was aimed to reveal the importance of this fish in terms of both biological and human health by introducing fatty acid profiles and making total fatty acid analysis in muscle tissue of this fish, which is consumed as an economically important source of nutrition in Eastern Anatolia region.

\section{MATERIALS AND METHODS}

\section{Collection of Samples}

Yeşil Su Village (3846'55.69"K, 43¹7'19.56"D, 1648m) Van Lake, which is close to the Van province, was selected as sampling stations. Fish were caught using blind (pulling) nets through local fishermen in the region. Three males and females were selected for analysis.

\section{Sex Determination}

The abdominal areas of the caught fish were opened with the help of dissection scissors and their sexes were determined by morphological observation of the gonads. In young samples, sex was determined by examining a piece taken from gonads under a light microscope.

\section{Lipid Extraction and Gas Chromatography Conditions}

Lipid Extraction was performed according to Folch (1957) the method of chloroform/methanol (2: $1 \mathrm{v} / \mathrm{v})$. Fatty acids of fat samples converted into methyl esters were analyzed using a SHIMADZU GC 2010 PLUS model Gas Chromatography instrument, flame ionization detector (FID) ve DB-23 (Bonded $50 \%$ cyanopropyl) (J \& W Scientific, Folsom, CA, USA) capillary column (30m x 0.25mm inner diameter $\times 0.25 \mu \mathrm{m}$ film thickness). The temperature program used was as follows. The initial temperature $\left(170{ }^{\circ} \mathrm{C}\right)$ was kept for $8 \mathrm{~min}$, raised to $190{ }^{\circ} \mathrm{C}$ at a rate of $2{ }^{\circ} \mathrm{C} \mathrm{min}^{-1}$ and kept at $190{ }^{\circ} \mathrm{C}$ for 
$17 \mathrm{~min}$, raised to $220^{\circ} \mathrm{C}$ at a rate of $10{ }^{\circ} \mathrm{C} \mathrm{min}^{-1}$, and maintained at this temperature for $10 \mathrm{~min}$. The injection and the detector temperatures were $250^{\circ} \mathrm{C}$. The split ratio was $40 / 1$.Chromatograms for methyl esters of fatty acids and total amounts of fatty acids were obtained using the GC Solution (Version 2.4) computer software. The peaks in the chromatogram of the analyzed samples were identified by comparing the retention times of the methyl esters of all fatty acids in the standard. The results are given as qualitative value as \% fatty acid. Percentages of fatty acid were compared with SPSS 16 computer program by using one-way analysis of variance (ANOVA). The differences were determined by the TUKEY HSD test. As a result of the statistics, the differences were accepted to be significant when the data was at $\mathrm{P}<0.05$ level.

\section{RESULTS AND DISCUSSION}

Especially the major components of the fish we analyzed did not show significant differences in different seasons.16:0 was found to be higher, albeit slightly, towards the end of the summer season (August) in the male and female individuals. There were no major changes in other seasons. It has been noted that oleic acid decreased slightly in both sexes in the winter season (February), while it increased somewhat in fall in females and in summer in males (Table 1. and 2.).

Out of polyunsaturated, 20:4n-6 decreased in fall (October) in females and at the end of summer in males. DHA was slightly lower in fall compared to other seasons. Out of the other major components, 16:1n-7 and 20:5n-3 did not show significant variations among seasons. In female fish, $\sum$ SFA increased towards the end of summer (August) and $\sum$ MUFA increased, albeit slightly, in fall, while $\sum$ PUFA was close to each other in all seasons in females and decreased in late summer and fall in male fish (Tables 1. and 2.). Total SFA was found to be lower in both individuals compared to $\sum$ MUFA and $\sum$ PUFA in all analyzed months. In females, $\sum$ PUFA was high in winter and $\sum$ MUFA was high in fall, while $\sum$ PUFA was high in winter and spring and $\sum$ MUFA was high in fall in males. In all seasons analyzed for Pearl Mullet, out of $\sum$ SFA, 16:0; out of $\sum$ MUFA, 18:1n-9 and 16:1n-7; and out of $\sum$ PUFA, 22:6n-3 and 20:5n3 were determined as major.

Fatty acids can be found at low ratios in winter, since it is the period when many fish species minimize their nutritional activity and, out of food organisms, many planktonic organisms reproduce less in this period. Researches showed that fatty acids that change the most seasonally in fish are unsaturated acids, while saturated ones do not change much throughout the year.

Deng et al. (1976) found that the ratio of saturated fatty acids in muscle tissue of M. cephalus was 45.3\% in May, 43.6\% in June, 40.9\% in August, 51.4\% in October and 44.9\% in November. The researchers found that the ratio of palmitic acid out of total fatty acids was $25.1 \%$ in May, $26.1 \%$ in June, 21.5\% in August, 27.7\% in October, and 28.3\% in November. "According to Akpinar and Aksoylar (1988)", increase of the ratio of total PUFA and n-3 series fatty acid in G. rufa in spring is due to the high intake of these fatty acids in this season.

In his study on fatty acid composition in muscle tissue of C. c. umbla, Y1lmaz (1995) found that the ratio of MUFA varied between 26.76-34.44\%, and that of oleic acid changed between 18.95-25.73\% over the year. The researcher reported that the ratio of total MUFA in muscle tissue of female individuals was significantly higher in fall and winter than that in spring and summer, the ratio of PUFA and n-3 fatty acids in fish was at the maximum level in spring, and decreased remarkably at the end of summer (Y1lmaz, 1995). 
Table 1. The change of female Alburnus tarichi's muscle total fatty acid percentages by months

\begin{tabular}{|c|c|c|c|c|c|c|c|}
\hline Fatty acids & $\begin{array}{c}\text { February } \\
(\text { Mean } \pm \text { SE) }\end{array}$ & $\begin{array}{c}\text { April } \\
(\text { Mean } \pm \text { SE) }\end{array}$ & $\begin{array}{c}\text { June } \\
(\text { Mean } \pm \mathrm{SE})^{*}\end{array}$ & $\begin{array}{c}\text { August } \\
(\text { Mean } \pm \text { SE) }\end{array}$ & $\begin{array}{c}\text { October } \\
(\text { Mean } \pm \mathrm{SE})^{*}\end{array}$ & $\begin{array}{c}\text { December } \\
(\text { Mean } \pm \mathrm{SE})^{*}\end{array}$ & $\begin{array}{c}\text { Average } \\
(\text { Mean } \pm \text { SE) }\end{array}$ \\
\hline $14: 0^{\S}$ & $3.06 \pm 0.35$ & $3.25 \pm 0.31$ & $3.40 \pm 0.45$ & $3.41 \pm 0.47$ & $3.25 \pm 0.31$ & $3.10 \pm 0.19$ & $3.24 \pm 0.06$ \\
\hline $15: 0$ & $0.38 \pm 0.04$ & $0.36 \pm 0.01$ & $0.31 \pm 0.05$ & $0.32 \pm 0.02$ & $0.32 \pm 0.02$ & $0.32 \pm 0.01$ & $0.34 \pm 0.01$ \\
\hline $16: 0$ & $15.37 \pm 0.81$ & $14.71 \pm 1.40$ & $13.47 \pm 0.19$ & $17.73 \pm 1.04$ & $14.87 \pm 0.56$ & $13.48 \pm 0.26$ & $14.94 \pm 0.64$ \\
\hline $17: 0$ & $0.97 \pm 0.21$ & $0.77 \pm 0.10$ & $0.84 \pm 0.03$ & $0.38 \pm 0.02$ & $0.52 \pm 0.02$ & $0.60 \pm 0.02$ & $0.68 \pm 0.09$ \\
\hline 18:0 & $4.11 \pm 0.24$ & $3.93 \pm 0.37$ & $3.98 \pm 0.34$ & $4.88 \pm 0.80$ & $4.56 \pm 0.27$ & $3.96 \pm 0.04$ & $4.24 \pm 0.16$ \\
\hline$\sum$ S.F.A & $23.88 \pm 1.16$ & $23.03 \pm 1.40$ & $22.00 \pm 0.63$ & $26.73 \pm 2.81$ & $23.51 \pm 0.50$ & $21.46 \pm 0.07$ & $23.44 \pm 0.76$ \\
\hline $16: 1 n-7$ & $12.56 \pm 1.33$ & $12.50 \pm 0.52$ & $13.51 \pm 1.08$ & $13.48 \pm 2.25$ & $14.33 \pm 1.09$ & $13.31 \pm 0.35$ & $13.28 \pm 0.28$ \\
\hline $18: 1 n-9$ & $22.12 \pm 1.95$ & $24.75 \pm 3.04$ & $24.91 \pm 1.14$ & $21.67 \pm 3.12$ & $25.40 \pm 0.47$ & $23.30 \pm 0.19$ & $23.69 \pm 0.64$ \\
\hline $20: 1 n-9$ & $0.51 \pm 0.03$ & $0.53 \pm 0.22$ & $0.19 \pm 0.04$ & $0.09 \pm 0.07$ & $0.57 \pm 0.06$ & $0.69 \pm 0.04$ & $0.43 \pm 0.10$ \\
\hline$\sum$ M.U.F.A & $35.19 \pm 3.27$ & $37.78 \pm 1.39$ & $38.61 \pm 1.98$ & $35.25 \pm 4.87$ & $40.30 \pm 0.59$ & $37.30 \pm 0.33$ & $37.40 \pm 0.81$ \\
\hline $18: 2 n-6$ & $3.75 \pm 0.66$ & $3.46 \pm 0.53$ & $3.47 \pm 0.33$ & $3.40 \pm 0.32$ & $3.16 \pm 0.32$ & $2.74 \pm 0.09$ & $3.33 \pm 0.14$ \\
\hline $18: 3 n-3$ & $2.07 \pm 0.29$ & $1.83 \pm 0.10$ & $1.63 \pm 0.34$ & $1.71 \pm 0.34$ & $1.59 \pm 0.18$ & $1.56 \pm 0.04$ & $1.73 \pm 0.08$ \\
\hline $20: 2 n-6$ & $0.60 \pm 0.07$ & $0.55 \pm 0.07$ & $0.67 \pm 0.07$ & $0.31 \pm 0.05$ & $0.42 \pm 0.02$ & $0.54 \pm 0.02$ & $0.52 \pm 0.05$ \\
\hline $20: 3 n-6$ & $1.46 \pm 0.74$ & $0.70 \pm 0.03$ & $1.01 \pm 0.13$ & $0.49 \pm 0.06$ & $0.64 \pm 0.06$ & $0.77 \pm 0.03$ & $0.84 \pm 0.14$ \\
\hline $20: 4 n-6$ & $3.07 \pm 0.14$ & $3.66 \pm 0.57$ & $3.27 \pm 0.97$ & $3.23 \pm 1.03$ & $2.78 \pm 0.11$ & $3.10 \pm 0.11$ & $3.19 \pm 0.12$ \\
\hline $20: 5 n-3$ & $11.99 \pm 2.22$ & $10.56 \pm 0.77$ & $11.43 \pm 0.51$ & $11.85 \pm 0.67$ & $11.22 \pm 0.31$ & $12.53 \pm 0.67$ & $11.60 \pm 0.28$ \\
\hline $22: 5 n-3$ & $4.89 \pm 0.48$ & $5.47 \pm 0.26$ & $6.32 \pm 0.09$ & $3.80 \pm 0.33$ & $5.59 \pm 0.58$ & $6.03 \pm 0.17$ & $5.35 \pm 0.37$ \\
\hline $22: 6 n-3$ & $13.09 \pm 1.71$ & $12.96 \pm 0.92$ & $11.59 \pm 0.97$ & $13.23 \pm 1.15$ & $10.78 \pm 1.16$ & $13.98 \pm 0.74$ & $12.61 \pm 0.48$ \\
\hline$\sum$ P.U.F.A & $40.92 \pm 4.43$ & $39.19 \pm 1.42$ & $39.39 \pm 1.66$ & $38.03 \pm 2.22$ & $36.19 \pm 1.09$ & $41.24 \pm 0.27$ & $39.16 \pm 0.77$ \\
\hline$n-3$ & $32.04 \pm 3.99$ & $30.82 \pm 1.36$ & $30.97 \pm 1.30$ & $30.59 \pm 0.96$ & $29.19 \pm 1.25$ & $34.09 \pm 0.16$ & $31.28 \pm 0.67$ \\
\hline$n-6$ & $8.88 \pm 0.53$ & $8.37 \pm 0.44$ & $8.42 \pm 0.71$ & $7.43 \pm 1.28$ & $7.00 \pm 0.26$ & $7.15 \pm 0.11$ & $7.88 \pm 0.32$ \\
\hline$n-3 / n-6$ & 3.61 & 3.68 & 3.68 & 4.12 & 4.17 & 4.77 & 3.97 \\
\hline
\end{tabular}

Values are provided as mean $\pm \mathrm{SE}$

SFA saturated fatty acid, MUFA monounsaturated fatty acid, PUFA polyunsaturated fatty acid

Table 2. The change of male Alburnus tarichi's muscle total fatty acid percentages by months

\begin{tabular}{|c|c|c|c|c|c|c|c|}
\hline Fatty acids & $\begin{array}{c}\text { February } \\
(\text { Mean } \pm \text { SE) }\end{array}$ & $\begin{array}{c}\text { April } \\
(\mathrm{Mean} \pm \mathrm{SE})^{*}\end{array}$ & $\begin{array}{c}\text { June } \\
(\text { Mean } \pm \mathrm{SE})^{*}\end{array}$ & $\begin{array}{c}\text { August } \\
(\text { Mean } \pm \text { SE) }\end{array}$ & $\begin{array}{c}\text { October } \\
(\text { Mean } \pm \mathrm{SE})^{*}\end{array}$ & $\begin{array}{c}\text { December } \\
(\text { Mean } \pm \text { SE) }\end{array}$ & $\begin{array}{c}\text { Average } \\
(\text { Mean } \pm \text { SE) }\end{array}$ \\
\hline $14: 0$ & $2.85 \pm 0.30$ & $2.84 \pm 0.19$ & $2.32 \pm 0.07$ & $3.41 \pm 0.51$ & $3.58 \pm 0.38$ & $3.55 \pm 0.38$ & $3.09 \pm 0.21$ \\
\hline $15: 0$ & $0.37 \pm 0.01$ & $0.33 \pm 0.01$ & $0.23 \pm 0.02$ & $0.27 \pm 0.04$ & $0.33 \pm 0.02$ & $0.32 \pm 0.01$ & $0.31 \pm 0.02$ \\
\hline $16: 0$ & $16.67 \pm 0.44$ & $15.15 \pm 1.25$ & $14.12 \pm 0.29$ & $16.92 \pm 0.55$ & $15.72 \pm 0.43$ & $13.43 \pm 0.30$ & $15.34 \pm 0.57$ \\
\hline $17: 0$ & $0.74 \pm 0.05$ & $0.68 \pm 0.18$ & $0.70 \pm 0.02$ & $0.20 \pm 0.03$ & $0.51 \pm 0.10$ & $0.61 \pm 0.03$ & $0.57 \pm 0.08$ \\
\hline $18: 0$ & $4.68 \pm 0.30$ & $4.38 \pm 0.14$ & $4.73 \pm 0.27$ & $4.14 \pm 0.44$ & $4.39 \pm 0.36$ & $3.84 \pm 0.24$ & $4.36 \pm 0.14$ \\
\hline$\sum$ S.F.A & $25.32 \pm 0.45$ & $23.38 \pm 1.03$ & $22.11 \pm 0.23$ & $24.93 \pm 1.23$ & $24.53 \pm 0.80$ & $21.75 \pm 0.21$ & $23.67 \pm 0.61$ \\
\hline $16: 1 n-7$ & $11.36 \pm 0.89$ & $12.87 \pm 0.59$ & $10.62 \pm 0.03$ & $13.74 \pm 0.85$ & $15.53 \pm 0.56$ & $14.86 \pm 1.01$ & $13.16 \pm 0.79$ \\
\hline $18: 1 n-9$ & $20.63 \pm 1.41$ & $22.35 \pm 1.62$ & $24.68 \pm 1.69$ & $27.73 \pm 1.26$ & $25.75 \pm 1.41$ & $25.70 \pm 0.57$ & $24.47 \pm 1.05$ \\
\hline $20: 1 n-9$ & $0.56 \pm 0.09$ & $0.09 \pm 0.03$ & $0.14 \pm 0.01$ & $0.04 \pm 0.02$ & $0.56 \pm 0.07$ & $0.66 \pm 0.06$ & $0.34 \pm 0.12$ \\
\hline$\sum$ M.U.F.A & $32.54 \pm 2.14$ & $35.31 \pm 2.19$ & $35.44 \pm 1.66$ & $41.50 \pm 1.38$ & $41.85 \pm 0.83$ & $41.22 \pm 1.38$ & $37.98 \pm 1.64$ \\
\hline $18: 2 n-6$ & $3.83 \pm 0.40$ & $3.29 \pm 0.12$ & $3.31 \pm 0.39$ & $3.57 \pm 0.92$ & $2.80 \pm 0.12$ & $2.84 \pm 0.09$ & $3.28 \pm 0.16$ \\
\hline $18: 3 n-3$ & $1.94 \pm 0.25$ & $2.03 \pm 0.15$ & $1.37 \pm 0.08$ & $1.28 \pm 0.13$ & $1.66 \pm 0.10$ & $1.74 \pm 0.04$ & $1.67 \pm 0.12$ \\
\hline $20: 2 n-6$ & $0.91 \pm 0.33$ & $0.58 \pm 0.04$ & $0.73 \pm 0.12$ & $0.27 \pm 0.02$ & $0.38 \pm 0.06$ & $0.47 \pm 0.02$ & $0.56 \pm 0.10$ \\
\hline $20: 3 n-6$ & $0.72 \pm 0.03$ & $0.78 \pm 0.03$ & $0.84 \pm 0.05$ & $0.41 \pm 0.10$ & $0.70 \pm 0.09$ & $0.74 \pm 0.06$ & $0.70 \pm 0.06$ \\
\hline $20: 4 n-6$ & $3.89 \pm 0.25$ & $4.16 \pm 1.05$ & $3.69 \pm 0.43$ & $2.53 \pm 0.66$ & $2.89 \pm 0.05$ & $2.80 \pm 0.16$ & $3.33 \pm 0.27$ \\
\hline $20: 5 n-3$ & $12.19 \pm 1.50$ & $12.16 \pm 0.80$ & $11.12 \pm 1.03$ & $9.89 \pm 1.34$ & $10.00 \pm 0.67$ & $10.19 \pm 0.27$ & $10.93 \pm 0.43$ \\
\hline $22: 5 n-3$ & $5.04 \pm 0.16$ & $5.38 \pm 0.58$ & $6.74 \pm 0.54$ & $3.69 \pm 0.21$ & $4.71 \pm 0.06$ & $5.85 \pm 0.27$ & $5.23 \pm 0.42$ \\
\hline $22: 6 n-3$ & $13.61 \pm 0.84$ & $12.92 \pm 0.83$ & $14.65 \pm 0.75$ & $11.93 \pm 2.43$ & $10.48 \pm 0.52$ & $12.40 \pm 0.97$ & $12.67 \pm 0.59$ \\
\hline$\sum$ P.U.F.A & $42.13 \pm 1.69$ & $41.30 \pm 1.47$ & $42.46 \pm 1.65$ & $33.57 \pm 3.69$ & $33.62 \pm 1.23$ & $37.03 \pm 1.29$ & $38.35 \pm 1.70$ \\
\hline$n-3$ & $32.77 \pm 2.05$ & $32.49 \pm 1.89$ & $33.88 \pm 1.62$ & $26.79 \pm 4.03$ & $26.85 \pm 1.22$ & $30.18 \pm 1.26$ & $30.49 \pm 1.26$ \\
\hline$n-6$ & $9.36 \pm 0.36$ & $8.82 \pm 0.95$ & $8.57 \pm 0.18$ & $6.78 \pm 0.70$ & $6.78 \pm 0.25$ & $6.85 \pm 0.08$ & $7.86 \pm 0.48$ \\
\hline$n-3 / n-6$ & 3.50 & 3.69 & 3.95 & 3.95 & 3.96 & 4.41 & 3.88 \\
\hline
\end{tabular}

Values are provided as mean $\pm \mathrm{SE}$

SFA saturated fatty acid, MUFA monounsaturated fatty acid, PUFA polyunsaturated fatty acid 
PUFAs were found to be higher than MUFAs and SFAs in all seasons in zander living in Lake Beyşehir. The percentage of oleic acid was not so much affected by the season. The amount of DHA, which was in the range of 17.1-23.3\% of total fatty acids, varied depending on the season. The ratio of total PUFAs decreased in winter due to the gonad maturation (Guler et al., 2007).

In a study carried out on C. carpio in Lake Beyşehir, it was found that polyunsaturated fatty acids were in higher amounts than saturated ones in the spring, summer, and fall, that 16:0 was the most abundant one as a percentage (14.6-16.6\%) in all seasons, and that 18:1n-9 was the main MUFA (15.120.3\%). Docosahexaenoic acid was the main PUFA in summer and winter, whereas 18:2n-6 was the main one in spring and fall. The data obtained show that the fatty acid content in the muscle of the carp is affected by the season and feeding period. Low amounts of 16:1n-7 reduced the MUFA content in carp, while the high percentage of DHA (11\%) increased the content of PUFA in the summer. The low ratio of 18:2n- 6 in winter also reduced the ratio of PUFA. It has been suggested that low PUFA content $(29.3 \%)$ in winter in carp depends on the season (Güler et al., 2008).

16:0 in C. carpio, S. triostegus and T. grpus from Atatürk Dam Lake increased in summer and in the beginning of fall, while 22:6n-3 decreased in the last period of spring. Percentage of $\sum$ SFAs increased in summer and fall in C. carpio and S. triostegus. In males of $C$. carpio and in male and female individuals of $S$. triostegus, PUFA increased in winter, whereas 20:5n-3 increased in fall in C. carpio and T. grpus (Kaçar, 2010).

The amounts of 20:4n-6, 22:5n-3, and 22:6n-3 in C. chalcoides and L. cephalus started to decrease as of July and decreased to the lowest level in September, which represents the fall period. There was an increase in their amounts with the winter period. Total SFA in the muscle tissue of all three species decreased in winter (Görgün, 2011).

In the case of total lipid of the dorsal muscle of S. triostegus, which was analyzed for a year, total monounsaturated fatty acids increased in summer, while total polyunsaturated ones increased in winter and spring. Out of the monounsaturated fatty acids, 16:1n-7 was higher in fall and summer, 18:1n-9 in summer; out of n- 6 polyunsaturated fatty acids, 18:2n-6 in fall and winter, 20:4n-6 in spring and winter; out of n-3 polyunsaturated fatty acids, 18:3n-3 in winter, 20:5n-3 and 22:6n-3 in spring compared to the other seasons (Cengiz et al., 2012).

Fatty acid quantitative content in dorsal muscle total lipid of $C$. trutta varied depending on the season. In the case of dorsal muscle total lipid of $C$. trutta, total MUFA in summer and total PUFA at other times were found to be at a higher rate compared to the other analyzed periods. Total SFA and MUFA increased in summer, while total PUFA increased in fall. Out of the individual fatty acids, 16:0 increased in winter and summer, 16:1n-7 in summer, 18:1n-9 in winter and summer, 22:6n-3 in spring, 18:2n-6 in winter, $20: 4 n-6$ in fall compared to the other seasons. The ratio of total $n-3$ was found between $26.51 \%$ (summer) - $40.77 \%$ (spring), while that of total $n-6$ was between $6.45 \%$ (summer)-21.45\% (fall) (Satar et al., 2012).

The percentage of saturated fatty acids in Pearl Mullet was determined mostly in summer. It has been suggested that these components are of low value and close to each other in spring, fall, and winter (Duyar, 1995).

In our study, the data we obtained from the analysis of fatty acids in the muscle tissue of Pearl Mullet in different seasons are in agreement with some other studies. For instance, as in many studies (Duyar, 1995; Kaçar, 2010; Satar et al., 2012), we found that the percentage of 16:0 and total SFA in Pearl Mullet was higher in summer. The increase and decrease of total MUFA, total PUFA and the fatty acids forming them change in different seasons. For example, as in S. triostegus (Satar et al., 2012) and 
C. trutta (Satar et al., 2012) taken from the Tigris River, in our study, total MUFAs increased in summer in males.

The amounts of DHA in freshwater fish and the distribution of this component by the seasons differ between species even if they are collected from the same lake. For example, the ratio of 22:6n-3 in zander fish from Lake Beyşehir varied between 17.1-23.3\% depending on the season. This component was found mostly in spring and at least in summer (Güler et al., 2007). In contrast, the ratio of DHA in C. carpio collected from the same lake varied between $4.32-11.0 \%$ depending on the season. This fatty acid was found mostly in summer and at least in fall (Güler et al., 2008).

It was determined that the percentage of DHA in the fish we analyzed was close to each other in all months representing different seasons.

As in V. v. tenella from Lake Eğirdir (Kalyoncu et al., 2009) and in much freshwater fish, out of in MUFA, 18:1n-9 and out of PUFAs, 22:6n-3 was major in all three fish species we analyzed. As seen, the most abundant type of fatty acid in terms of the percent distribution in SFA, MUFA, and PUFA are similar among fish.

The ratio of PUFA in zander (Güler et al., 2007) decreased in winter, the ratio in the three fish species in Atatürk Dam Lake (Kaçar, 2010) decreased in the first periods of spring and in summer, and in our study, it decreased in late summer and in the fall for male fish. This difference may be due to the fact that sources of water from which fish are taken are different.

The amounts of n-3 PUFA, n-6 PUFA, and EPA + DHA in the muscle of B. p. escherichi and $C$. c. capoeta were found higher in January than those in July. The amount of SFAs in B. p. esherichi and that of MUFAs in C. c. capoeta were found to be lower in January than in July. The ratio of MUFAs was higher than that of SFAs in both months (July and January) in the studied species. This result was found to agree with a study carried out on freshwater fish (Uysal et al., 2008).

As determined in the muscle of B. p. escherichi and C. c. capoeta in the previous study (Uysal et al., 2008), the amounts of n-3 PUFA, n-6 PUFA, EPA, and DHA in C. carpio, T. grypus, and S. triostegus were found higher in January than those in July. SFAs in both individuals of $C$. carpio, MUFAs in both individuals of S. triostegus, both SFAs and MUFAs in female and male individuals of T. grypus were lower in January than those in July.

MUFAs were found higher in all seasons than SFAs and PUFAs in V. v. tenella from Lake Eğirdir, which is the Turkey's second-largest lake (Kalyoncu et al., 2009).

In our study, $\sum$ SFA was found less than $\sum$ MUFA and $\sum$ PUFA in both individuals of Pearl Mullet in all analyzed months. $\sum$ PUFA was found high in winter and $\sum$ MUFA in fall in females, while $\sum$ PUFA was high in winter and spring, and $\sum$ MUFA in fall. This result shows that the fish is rich in especially unsaturated fatty acids in all seasons.

\section{CONCLUSION}

Herein, we examined the fatty acid distribution of pearl mullet, an endemic fish species, by months. Fatty acid analysis were given percentage distribution as quantitatively. As a result of the analysis, the fatty acid distribution is given in table 1 . and 2 . When in the analyses, the ratio of $\omega 3 / \omega 6$, which is important in terms of the nutritional value of fish, was determined as 3.97 on average in females and 3.88 on males. These components increased in December in both sexes, whereas they decreased in February. We determine $\sum$ SFA increased in August in both sexes, and $\sum$ MUFA increased in October, but $\sum$ PUFA decreased in the same month. In all analyzed months, $\sum$ MUFA and $\sum$ PUFA were more than $\sum$ SFA in both sexes. 


\section{ACKNOWLEDGEMENT}

This study was financially supported by Dicle University, Research Fund Project (Project no: DÜBAP13-FF-43).

\section{REFERENCES}

Ackman RG, 1989. Nutritional composition of fats in seafood. Progress in food and nutrition science. 13: $161-241$.

Ackman RG, 1990. Seafood lipids and fatty acids. Food Reviews International, 6 (4): 617-646.

Akpınar MA, Aksoylar MY, 1988. Garra rufa Heckel, 1843'nın yağ asidi bileşimine sıcaklığın, besinsel yağ asitlerinin ve açlığın etkileri. Türk Tarım ve Doğa Bilimleri Dergisi, 12(1): 1-8.

Atchison GJ, 1975. Fatty acid levels in developing Brook Trout (Salvenus fontinalis) eggs and fry. Journal of the Fisheries Research Board of Canada, 32: 2513-2515.

Berg OK, Thronaes E, Bremset G, 2000. Seasonal cycle of body composition and energy of Brown Trout (Salmo trutta) in a temperate zone lake. Ecology of Freshwater Fish, 9:163-169.

Castell JD, Lee DJ, Sinnhuber RO, 1972. Essential fatty acids in the diet of Rainbow Trout (Salmo gairdneri): Lipid metabolism and fatty acid composition. The Journal of Nutrition, 102: 93-100.

Cengiz Eİ, Ünlü E, Başhan M, Satar A, Uysal E, 2012. Effects of seasonal variations on the fatty acid composition of total lipid, phospholipid and triacylglicerol in the dorsal muscle of Mesopotamian catfish (Silurus triostegus Heckel, 1843) in Tigris River (Turkey). Turkish Journal of Fisheries and Aquatic Sciences. 12: 33-39.

Dave G, Johanson-Sjöbeek ML, Larsson A, Lewander K, Lidman U, 1976. Metabolic and hemetological effects of starvation in the European Eel. Anguilla anguilla L.-III. Fatty acid composition. Comparative Biochemistry and Physiology, 53(B): 509-515.

Dean LM, 1990. Nutrition and preparation, in R.E. Martin, G.J. Flick eds, The Seafood Industry 255267. Published Van Nostrand Rainhold, New York.

Deng JC, Orthefer FT, Dennison RL, Watson M, 1976. Lipids and fatty acids in Mullet (Mugil cephalus): Seasonal and locational variations. Journal of Food Science, 4, 1479-1483.

Duyar HA, 1995. İnci kefali (chalcalburnus tarichi pallas, 1811) kas ve yumurtasının kimyasal kompozisyonu ve kroket yapımı üzerinde bir araştırma. Ege Üniversitesi Fen Bilimleri Enstitüsü Su Ürünleri ve İşleme Teknolojisi Anabilim Dalı, Doktora Tezi, 118 s., İzmir.

Farkas T, Csengeri I, 1976. Biosynthesis of fatty acids by the Carp, Cyprinus carpio L., in relation to environmental temperature. Lipid, 11: 401-407.

Farkas T, Csengeri I, Majoros F, Olah J, 1978. Metabolism of fatty acids in fish. II. Biosynthesis of fatty acids in relation to diet in the Carp, Cyprinus carpio Linnaeus 1758. Aquaculture, 14: 57-65.

Feeley RM, Criner DEC, Watt BK, 1972. Cholesterol content of foods. Journal of the American Dietetic Association, 61; 134-48.

Folch J, Lees M, Sladane-Stanley GHA, 1957. Simple method for the isolation and purification of total lipids from animal tissues. J. Biol. Chem., 226: 497-509.

George R, Bhopal R, 1995. Fat composition of free living and farmed sea species: Implications for human diet and sea-farming. British Food Journal, 97:19-22.

Görgün S, 2011. Tödürge Gölü'nde (Sivas) yaşayan bazı Cyprinidae türlerinin karaciğer ve kas dokusu yağ asiti bileşiminin mevsimsel değişimi ve karaciğer lipaz enziminin saflaştırılması ve biyokimyasal özelliklerinin karşılaştırılması, Doktora tezi Cumhuriyet Üniversitesi Fen Bilimleri Enstitüsü, 212 sayfa. 
Güler GO, Aktümsek A, Çitil OB, Arslan A, Torlak E, 2007. Seasonal variations on total fatty acid composition of fillets of Zander (Sander lucioperca) in Beysehir Lake (Turkey). Food Chemistry, 103: 1241-1246.

Güler GO, Kıztanır B, Aktümsek A, Çitil OB, Özparlak H, 2008. Determination of the seasonal changes on total fatty acid composition and n-3/n-6 ratios of Carp (Cyprinus carpio L.) muscle lipids in Beysehir Lake (Turkey). Food Chemistry, 108: 689-694.

Huss H, 1988. Fresh fish quality and quality changes. Ministery of Fisheries Technical Universty Press, Copanhagen, Denmark.

Kaçar S, 2010. Atatürk Baraj Gölü'nden toplanan Ctprinus carpio, Tor grypus ve Silurus triostegus'un kas, gonat ve karaciğerindeki total lipit ile fosfolipit ve triaçilgliserol fraksiyonlarındaki yağ asitlerinin mevsimsel içeriğinin incelenmesi. Dicle Üniversitesi Fen Bilimleri Enstitüsü Biyoloji A.B.D. Doktora tezi. 2010

Kalyoncu L, Kissal S, Aktumsek A, 2009. Seasonal changes in the total fatty acid composition of Vimba, Vimba vimba tenella (Nordmann, 1840) in Eğirdir Lake. Food Chemistry, 116: 728-730.

Nettleton JA, Exler J, 1992. Nutrients in wild and farmed fish and shellfish. Journal of Food Science, 57: 257-260.

Osaka K, Yamaguchi A, Kurokawa T, Kuwahara K, Saito H et al, 2002. Chemical components and body color of Horse Mackerel caught in different areas. Fisheries Science, 68:587-594.

Osibona AO, Kusemiju K, Akande GR, 2009. Proximate composition and fatty acids profile of the African Catfish (Clarias gariepinus). acta Satech 3(1): 85-89.

Reilly MP, Lawson JA, Fitzgerald GA, 1998. Eicosanoids and isoeicosanoids: Indices of cellular function and oxidant stress. The Journal of Nutrition, 128: 434-438.

Sarı M, 1997. Van Gölü İnci Kefalinin (Chalcalburnus tarichi, Pallas, 1811) stok miktarının tayini ve balıkçılık yönetim esaslarının belirlenmesi (Doktora Tezi). E Ü. Fen Bilimleri Enstitüsü, İzmir, $85-117 \mathrm{~s}$.

Satar E, Uysal E, Ünlü E, Başhan M, Satar A, 2012. The effects of seasonal variation on the fatty acid composition of total lipid, phospholipid, and triacylglycerol in the dorsal muscle of Capoeta trutta found in the Tigris River (Turkey). Turkish Journal of Biology, 36 (1), 113-123 .

Steffens W, Wirth M, 2005. Freshwater fish - an important source of n-3 polyunsaturated fatty acids. Archives of Polish Fisheries, 13 (1): 5-16.

Su XQ, Antonas KN, Li D, 2004. Comparison of n-3 polyunsaturated fatty acid contents of wild and cultured Australian abalone. International Journal of Food Sciences and Nutrition, 55:149-154.

Uysal K, Aksoylar MY, 2005. Seasonal variations in fatty acid composition and the n-6/n-3 fatty acid ratio of pikeperch (Sander lucioperca) muscle lipids. Ecology of Food and Nutrition. 44: 23-35.

Uysal K, Bülbül M, Dönmez M, Seçkın AK, 2008. Changes in some components of the muscle lipids of three freshwater fish species under natural extreme cold and temperate conditions. Fish Physiology and Biochemistry, 34, 455-463.

Whelan J, Surette ME, Hardarottir I, 1993. Dietary arachidonate enhances tissue arachidonate levels and eicosanoid production in Syrian hamsters. The Journal of Nutrition, 123: 2174-2185.

Y1lmaz Ö, 1995. Elazı̆̆ Hazar Gölü'nde yaşayan Capoeta capoeta umbla (Heckel, 1843)'nın total yăg asidi miktarı ve yağ asitleri cinslerinin mevsimlere göre değişimi. Fırat Üniv. Fen Bil. Enst Biyoloji A.B.D., Doktora Tezi, 120s. Elazı̆̆ 